Zapotoczna M., Poczobutt M., The Register of Dishonest Tenants as a solution to problems on the real estate market, „Ekonomia i Prawo. Economics and Law”, Polszakiewicz B., Boehlke J. (ed.), Vol. 15, No. 2/2016, pp. 249-260. DOI: http://dx.doi.org/10.12775/EiP.2016.016.

\title{
THE REGISTER OF DISHONEST TENANTS AS A SOLUTION TO PROBLEMS ON THE REAL ESTATE MARKET
}

\author{
SUMMARY
}

The study analyzes the problems encountered by property lessors in dealing with dishonest tenants on the Polish rental market. The article proposes a new legal tool, a Register of Dishonest Tenants (RDT), which would provide property owners with more extensive rights in protecting their property against dishonest lessees. The main objective was achieved in three steps: 1) the legal regulations and the literature relating to lease contracts were analyzed; 2) the situation on the Polish rental market was discussed; 3) the proposed legal tool for protecting property owners against dishonest tenants was presented. The authors also postulated the need to introduce legal definitions of the terms "dishonest tenant" (the definition is formulated in the article) and "commercial premises", including their functions.

The authors argue that the proposed legal instrument could be an effective and rational solution to the growing problem of dishonest tenancy. The presented RDT would protect the interests of landlords and would contribute to the effectiveness of the rental market in Poland.

Keywords: property market; register of dishonest tenants

JEL Classification: K12; R30

" Marcelina Zapotoczna, University of Warmia and Mazury, Faculty of Economics, Department of Finance and Banking, ul. Oczapowskiego 2, 10-719 Olsztyn, Poland, phone: +48 895233 398, e-mail: imz@uwm.edu.pl (corresponding author).

* Marcin Poczbutt, Poczobutt and Pietkun Law Office, a Partnership, in Olsztyn, ul. Kołobrzeska 13/316, 10-444 Olsztyn, Poland, phone: +48 501511 859, e-mail: m_ poczobutt@tlen.pl. 


\section{INTRODUCTION}

Lease and tenancy are civil law contracts regulated by several acts of Polish law. The Civil Code is the key legal act that comprehensively deals with the nature and subject matter of lease contracts ${ }^{1}$. A lease contract is an institution of the law of obligations which regulates the right to use another person's property. This article focuses on tenancy, namely the lease of residential and commercial premises to tenants, which has similar features to the institution of property law. This similarity results from the legislator's attempts to regulate tenancy relations, which has led to the breakdown of the initially homogeneous structure of lease and the isolation of the concept of tenancy from the general body of the applicable laws. The article proposes the concept of a Register of Dishonest Tenants (RDT), a legal instrument that would more effectively protect the interests of landlords in a confrontation with dishonest tenants and would contribute to the effectiveness of the rental property market in Poland. In the first part of the article, the authors analyzed the legal regulations and the literature relating to lease contracts. The present status of property owners was discussed to emphasize the dire need for new legal instruments that would force dishonest tenants to assume responsibility for their misconduct. The subsequent part of the article is dedicated to the proposed RDT concept which is based on the existing Register of Insolvent Debtors (RID). The authors argue that in order for the RDT to be effective, the concepts of a dishonest tenant (proposed in the article) and commercial property, with an indication of its functions, should be statutorily defined.

\section{NATURE OF TENANCY AND LEGAL REQUIREMENTS}

Pursuant to the provisions of Art. $659 \S 1$ of the Civil Code, a tenancy contract (essentialia negotii) is a contract by which the owner of real property (landlord) grants possession of that real property, for a specified or unspecified period of time, to the tenant in exchange for the tenant's payment of rent. A legal obligation arises consensually between the parties to the tenancy contract. The resulting legal relationship is mutual, it is effected for reward, and the property in question does not have to be made available to the tenant before the tenancy contract is effectively concluded (Art. 662, §1 of the Civil Code), but under extraordinary circumstances, this relationship can be

${ }^{1}$ Ustawa z dnia 23 kwietnia 1964 r. Kodeks cywilny (Civil Code), Dz.U. 1964, No. 16, item 93, Art. 659-692. 
established by force of law (Art. $680^{1}$ and Art. 691 of the Civil Code, Art. 16 of the Act on housing cooperatives ${ }^{2}$. The legal relationship between the parties to a tenancy contract is governed by the principle of freedom of contract (Art. $353^{1}$ of the Civil Code). Excluding the provisions of Art. 660 and Art. 678 §2, the Civil Code does not prescribe the form of a tenancy contract. There are no formal or legal obstacles that would bar the conclusion of a tenancy contract orally or even per facta concludentia (with a reservation for the provisions of Art. 660). For the contract to be legally binding, however, the parties are strongly advised to deliver it in writing. The parties to the contract are the landlord and the tenant. A tenancy contract can be executed by every legal entity, although certain exceptions apply to the tenant under the provisions of detailed regulations. The tenant can share the possession of property with other tenants. The parties to a continuous tenancy contract can undergo subjective transformation. Matters not regulated by the Civil Code (Art. 680-692) fall subject to the general tenancy laws.

\subsection{TENANT'S RIGHTS AND RESPONSIBILITIES}

Payment of rent is the tenant's main responsibility to the landlord. In most cases, rent is stipulated as a sum of money, and it is governed by the provisions of Civil Code that apply to monetary performance. The parties can also agree to fix the rent according to a measure of value other than money (Art. $358^{2} \S 2$ ), and they can introduce indexation clauses to the contract. The amount of rent is also fixed in residential tenancy contracts, but regulated rents play an important role in residential rental property ${ }^{3}$. Tenancy can be entered into the land and mortgage register, in chapter three ${ }^{4}$. The tenant can terminate the contract without notice if the rented property has defects that pose a health threat for the tenant or his employees (Art. 682 of the Civil Code). The tenant is responsible for covering the cost of minor repairs resulting from normal wear and tear, notifying the landlord of the neces-

2 Ustawa z dnia 15 grudnia 2000 r. o spótdzielniach mieszkaniowych (The Act on housing cooperatives of December 15, 2000), Dz.U. 2001, No. 4, item 27.

${ }^{3}$ Ustawa z dnia 21 czerwca 2001 r. o ochronie praw lokatorów, mieszkaniowym zasobie gminy i o zmianie Kodeksu cywilnego (Act on the protection of tenant rights, municipal housing resources and amendments to the Civil Code of June 21, 2001), Dz.U. 2001, No. 71, item 733, Art. 32, 37, 8a, 9; Ustawa z dnia 23 kwietnia 1964 r. Kodeks cywilny (Civil Code), Dz.U. 1964, No. 16, item 93, Art. $685^{1}$ and $688^{1}$.

${ }^{4}$ Ustawa z dnia 6 lipca 1982 r. o ksiegach wieczystych $i$ hipotece (Act on land and mortgage registers and mortgages of July 6, 1982), Dz.U. 1982, No.19, item147, Art. 16 paragraph 2 point 1 and Art. 25 paragraph. 1 points. 3. 
sary major repairs (Art. $662 \S 2$ of the Civil Code). The tenant may not sublet the property, for a payment or at no charge, without the landlord's explicit consent (Art. $688^{2}$ of the Civil Code). The tenant is under obligation to return the property to the landlord in substantially the same condition as it was at the beginning of tenancy (Art. $675 \$ 1$ of the Civil Code). The tenant is responsible for using the property in a manner specified in the contract and in accordance with the intended purpose of the property (Art. 666 and Art. $667 \S 1$ of the Civil Code).

\subsection{LANDLORD'S CLAIMS}

The landlord has the right to take the following action against tenants who fail to observe the provisions of the tenancy contract:

1. the landlord can demand the payment of all past due rent with statutory or contractual interest (Art. $669 \$ 1$ of the Civil Code in connection with Art. 359 of the Civil Code $)^{5}$;

2. the landlord has the right to terminate the tenancy contract without notice:

- if the tenant is in arrears with at least two full rent payments, (Art. 672, subject to the provisions of Art. 687 of the Civil Code);

- if the tenant grossly or persistently violates house rules or, through his inappropriate behavior, renders the use of other premises in the building burdensome, (Art. 685 of the Civil Code);

- if the tenant uses the property in a manner that violates the provisions of the tenancy contract or the intended purpose of the property (Art. 667 $\S 2$ of the Civil Code);

3. the landlord has the right to request a security deposit,

4. the landlord has the right to request other types of security in the contract (blank promissory note, suretyship, transfer of ownership, contractual penalty, notarized assent to foreclosure).

Non-monetary claims, such as claims raised in virtue of a tenant's failure to observe other contractual provisions (property damage, illegal use of property for purposes not specified in the tenancy contract, illegal subletting, eviction proceedings), constitute a different category. The above measures can be

5 To secure the rent and other payments in arrears for more than one year, the landlord has a statutory pledge on the tenant's movables that have been brought into the rented property, unless such movables are not subject to attachment (Ustawa z dnia 23 kwietnia 1964 r. Kodeks cywilny (Civil Code), Dz.U. 1964, No. 16, item 93, Art. 670). 
taken by the landlord to minimize the risks associated with dishonest tenants, but they do not effectively protect property owners.

\section{POLISH RENTAL PROPERTY MARKET}

The Polish real estate market does not have a fully developed rental property segment. For that market to develop optimally, the relations between the landlord and the tenant have to be clearly regulated under a tenancy contract that adequately protects the landlord's interests. New legal tools are also required to protect landlords against dishonest tenants. According to the authors, the RDT would offer such protection. The proposed register would protect the interests of landlords who rent commercial and residential property to businesses. Landlords operating on the commercial rental market are particularly at risk of dishonest behavior which is often not penalized.

Pursuant to the provisions of Art. 46 of the Civil Code, real property is subdivided into land, buildings and premises, but in view of significant differences in real property and the applied criteria, researchers have proposed various classification systems ${ }^{6}$. Commercial property is identified mainly based on economic criteria ${ }^{7}$. According to researchers ${ }^{8}$, commercial property is a source of income, and it can serve various functions. In view of the above, the proposed register would cover dishonest tenants who:

- rent residential premises intended for sale or rent,

- rent commercial premises intended for business operations and offices.

The proposed classification is largely arbitrary. The main problem is the absence of a legal definition of commercial premises and its functions, which can give rise to disputes concerning the subject matter of a tenancy contract ${ }^{9}$.

${ }^{6}$ E. Kucharska-Stasiak, Nieruchomości w gospodarce rynkowej, PWN, Warszawa 2006, pp. 14-15; T. Ramian, Funkcje i klasyfikacja nieruchomości, [in:] H. Henzel, Inwestycje na rynku nieruchomości, Wydawnictwo Akademii Ekonomicznej w Katowicach, Katowice 2004, pp. $27-40$.

${ }^{7}$ Classification criteria and a review of definitions of commercial property can be found in: A. Nalepka, Zarzqdzanie nieruchomościami. Wybrane zagadnienia, Wydawnictwo Akademii Ekonomicznej w Krakowie, Kraków 2006, p. 11; D. Trojanowski, Nieruchomość komercyjna i jej miejsce, "Nieruchomości C.H. Beck", No. 4/2002, p. 25; I. Foryś, Rynek nieruchomości komercyjnych, [in:] I. Foryś (ed.), Zarzadzanie nieruchomościami komercyjnymi, Poltext, Warszawa 2006, pp. 13-19.

${ }^{8}$ I. Foryś, Wstęp, [in:] I. Foryś (ed.), Zarządzanie nieruchomościami komercyjnymi, Poltext, Warszawa 2006, p. 11; I. Foryś, Rynek nieruchomości..., op. cit., pp. 29-31; 13-19.

9 According to the literature and jurisprudence, the concept of commercial premises should be analyzed based on the definition provided by other acts of law, in particular in the: Ustawa 
For this reason, the relevant definitions should be introduced to the applicable laws to guarantee that the RDT is an effective instrument.

\subsection{MARKET OF RESIDENTIAL RENTAL PROPERTY}

Due to historical reasons, the majority of Poles live in properties they own (83.8\%), whereas rental property still has a small share of the overall market. According to Eurostat data ${ }^{10}$, only $4.2 \%$ Poles rented apartments at market prices in 2013, which is significantly below the EU values. A relatively high percentage $(12 \%)$ of apartments were rented out on preferential terms, i.e. below market rent values or at no charge (municipal housing) (figure 1).

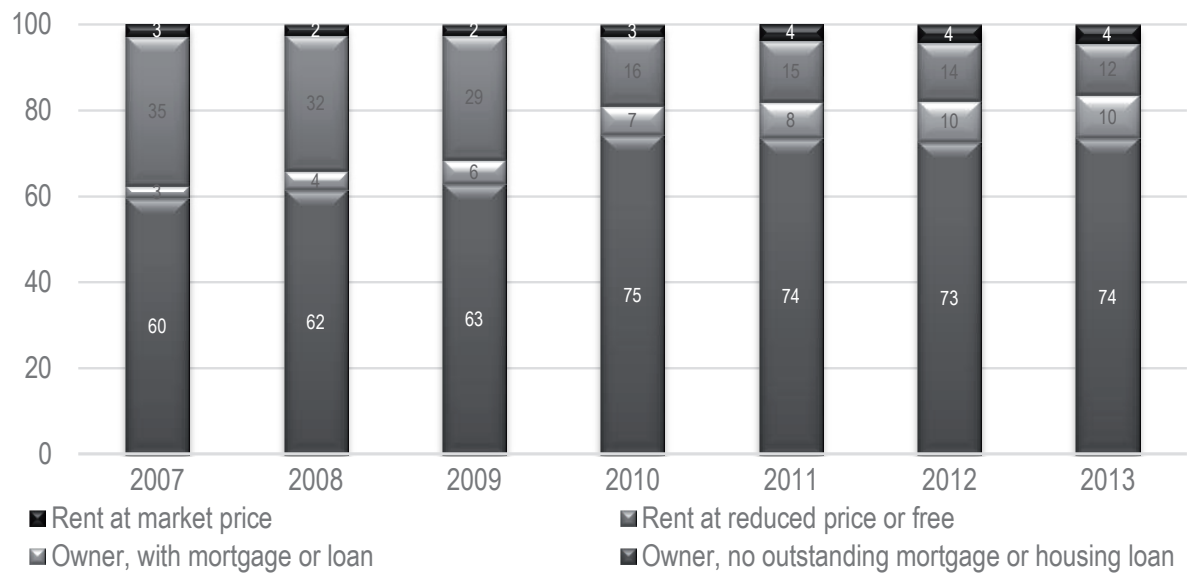

Figure 1. Distribution of population by tenure status (in \%)

Source: Own elaboration based on Eurostat data.

In all EU countries, including in Poland, the highest increase in tenure was reported in households with dependent children (figure 2).

z dnia 24 czerwca 1994 r. o wtasności lokali (Act on property ownership of June 24, 1994), Dz.U. 1994, No. 85, item 388.

${ }^{10}$ Eurostat, http://ec.europa.eu/eurostat (15.08.2015). 


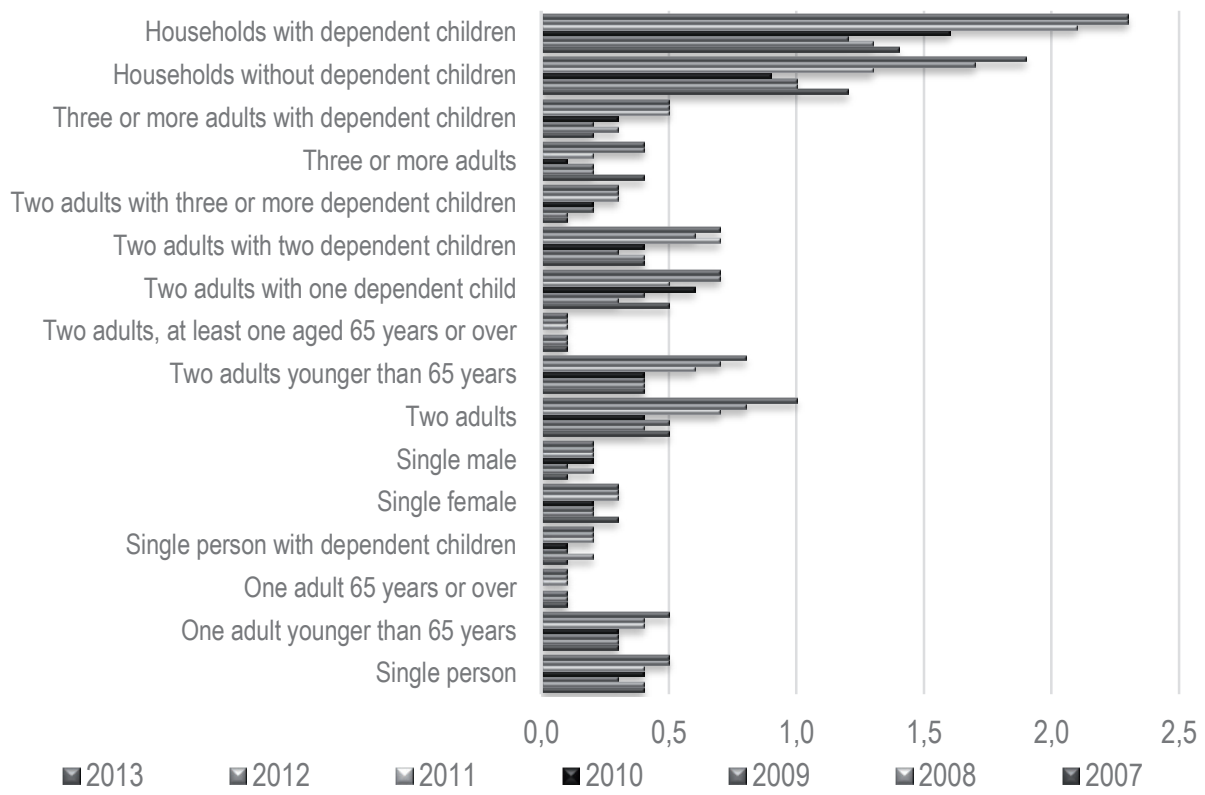

Figure 2. Distribution of tenants on the market of residential rental property with market rents (in \%) Source: Own elaboration based on Eurostat data.

The rental market poses a natural alternative to local property markets. The growth of the rental property market is prompted by changes in the mentality and lifestyles of Polish consumers, including declining marriage rates, higher divorce and separation rates and the resulting increase in the number of single-person households, decreasing attachment to one's birth place and growing mobility on the job market. The popularity of rental property has also increased because higher minimum down payment requirements lowered the availability of mortgages (10\% as of 1 January 2015 vs. 5\% in 2014). According to the literature ${ }^{11}$, banks' cautious policies, in particular with regard to the minimum down payment, can discourage consumers from buying property.

Public housing programs, which are regulated by the Act on selected incentives promoting housing construction ${ }^{12}$, and the Rental Property Fund addressed to consumers who have been preapproved and who conclude a fixed-

11 J.C. Stein, Prices and trading volumes in the housing market: a model with down-payment effects, "Quarterly Journal of Economics", Vol. 110, No. 2/1995, pp. 379-406.

12 Ustawa z dnia 26 października 1995 r. o niektórych formach popierania budownictwa mieszkaniowego oraz o zmianie niektórych ustaw (Act on selected incentives promoting housing construction of October 26, 1995), Dz.U. 1995, No. 133, item 654. 
term tenancy contract, also play an important role on the rental market. Capital and investments are required for that market to flourish. According to Augustyniak et al. ${ }^{13}$, privately-funded housing projects are burdened with numerous risks, including the risk of vacancy, termination of tenancy, unresolved problem of evicting illegal and defaulting tenants.

Significant changes can be expected on local rental property markets in view of the population projections developed by the Central Statistical Office (GUS) ${ }^{14}$ for 2014-2050.

\subsection{COMMERCIAL PROPERTY FOR RENT}

On the market of commercial property, lease is the main type of contract under which property is made available to the tenant. Both the landlord and the tenant should be familiar with the key elements and the structure of lease contracts in order to derive the highest possible profits from rented property. The Polish market of commercial property for rent continues to develop dynamically due to high levels of economic growth which stimulate demand among tenants ${ }^{15}$. According to the Cushman \& Wakefield ${ }^{16}$ report, the highest volume of investments in 1Q and 2Q 2015 was noted in the office market (47\%), followed by the market of retail property (34\%), industrial property and warehouses $(19 \%)^{17}$. From the managerial point of view, real estate can be classified as property that is occupied by one or many tenants. The observed high supply of new office space lowers rents and increases vacancy rates. On local office markets, developers offer various incentives for prospective tenants, including rent discounts, but such practices are difficult to apply in modern office buildings. On the market of retail property, supply is expected to increase by $30 \%$ in 2015 relative to the previous year ${ }^{18}$. The greatest increase in retail spaces for rent will take place in Poland's eight largest cities where the average vacancy rate is estimated at 3.1\%. In 2015, landlords have been

${ }^{13}$ H. Augustyniak et al., Kupić czy wynając? Analiza decyzji podmiotów na rynku mieszkaniowym determinowanych politykq mieszkaniowq. Raport o sytuacji na rynku nieruchomości mieszkaniowych $i$ komercyjnych w Polsce w 2012 r., Warszawa 2013, p. 116.

${ }^{14}$ Głowny Urząd Statystyczny, Prognoza ludności na lata 2014-2050, Warszawa 2014.

15 Cushman \& Wakefield, Dobre wyniki polskiego rynku nieruchomości komercyjnych, http:// www.cushmanwakefield.pl/pl-pl/news/2015/03/favourable-results-of-the-polish-commercialproperty-market (15.08.2015).

${ }^{16}$ Cushman \& Wakefield is a global leader in commercial real estate services.

17 Cushman \& Wakefield, Raport o rynku nieruchomości w Polsce. Jesień 2015, Warszawa 2015, pp. 4-5.

${ }^{18}$ Ibidem, p.12. 
able to strengthen their position on the market of retail property. In markets with a high supply of modern retail facilities, landlords renting out large spaces $\left(1000-2000 \mathrm{~m}^{2}\right)$ quote high interior design fees and introduce rent payments that are linked with the tenant's sales ${ }^{19}$. Establishments that provide services generally accompany retail property and offices.

On the warehouse market, the supply of new storage space commissioned for use in 1Q and 2Q of 2015 increased by 33\% from the previous year. Despite the high supply, the vacancy rate decreased by $0.6 \%{ }^{20}$. The warehouse market is highly dynamic, and the amount of storage space (in square meters) rented out in 2015 increased by more than $18 \%$ in comparison with the same period in 2014. The majority of transactions were new tenancy contracts, which indicates that the storage market continues to develop at a stable rate. Despite the noted growth, nominal rents on major warehouse markets did not change or even decreased ${ }^{21}$, and vacancy rates decreased on many local markets.

According to analysts, the continued pressure on the market of commercial property will increase supply. Developers are hoping to attract new tenants, including businesses that have just entered the market as well as occupants whose lease contracts are expiring and who will be offered more up-to-date property and more attractive terms of lease.

\section{REGISTER OF DISHONEST TENANTS - A PROJECT}

The RID, an existing instrument in the Polish legal system, does not provide landlords with effective protection against dishonest tenants. The market of residential and commercial property continues to develop rapidly, and new legal tools are needed to safeguard the interests of landlords confronted with dishonest tenants. Firstly, a system for verifying prospective tenants should be introduced as the standard measure on the Polish market of rental property, modeled on the example of its Western counterparts. Secondly, the tenancy contract should be carefully construed to ensure that the rights and responsibility of both parties are defined in detail. Owners of residential property greatly benefitted from the introduction of fixed-term tenancy (Art. 19a-19e of the Act on the protection of tenant rights). A fixed-term tenancy contract makes it easier for the landlord to evict defaulting tenants. However, tenants

\footnotetext{
${ }^{19}$ Ibidem, p. 16.

${ }^{20}$ Ibidem, p. 21.

${ }^{21}$ Ibidem, p. 23.
} 
who are willing and able to conclude a fixed-term contract are much more difficult to find in practice. For this reason, landlords often find it very difficult to protect their interests. Dishonest tenants are a massive problem on the Polish market of rental property. Most violators fail to pay the rent and utility charges. Intentional damage to property or use of property in a manner that is inconsistent with its intended purpose are also on the rise. Effective legal measures are needed to eliminate such practices. According to the authors, the problems caused by dishonest tenants and the scale of tenancy abuse on the rental market, despite the claims that can be instituted by the landlord in court, could be significantly alleviated by the proposed instrument. A Register of Dishonest Tenants should be established as a separate register or sub-register of the RID as a database of tenants who are in rent arrears or have other outstanding liabilities under the provisions of the civil law or the administrative law (mandatory tenant registration). The register could be modeled on the RID which was introduced by the Act of 20 August 1997 on the National Court Register (Art. 1 section 2 point 3, Journal of Laws of 2015, item 1142). The concept of a dishonest tenant should be introduced to the above Act because the relevant term is ambiguous, and it does not exist in civil law proceedings (which is why the name of the proposed register is based on the existing legal order). The proposed register should be made available to the general public, and all citizens would be entitled to information about a dishonest tenant via the National Information Center (Art. 8 of the above Act). Entries would be made in the register by the Regional Court (Business Court) upon the request of a creditor who has acquired a legally binding court judgment against a defaulting tenant, on a special form (KRS-D1 is presently used for requests to enter an insolvent debtor in the RID). At present, a court fee of PLN 300 is charged for every entry made in the RID (Art. 45 point 1 of the Act of 28 July 2005 on court fees in civil proceedings, Journal of Laws of 2010, No. 90, item 594, as amended), and the fee for deleting a register entry is PLN 150. To make the register more accessible to the general public, the above fees should be reduced by at least two-thirds. The National Information Center would make register data available via public ICT networks, including information on dishonest tenants, entries in the register and documents in the database. Fees could be charged for official extracts from the register. According to the authors, the fee for access to information about dishonest tenants should not exceed the standard processing fee which presently amounts to PLN 6 per page. The existing RID forms (KRS-D1, CI KRS-CDT, CI KRS-CDO) could be used in the RDT. The establishment of the proposed register would require amendments 
to the Act on the National Court Register and the respective Regulation of the Minister of Justice.

\section{CONCLUSIONS}

This article analyzes the rental property market in Poland. The authors have proposed a new legal instrument, the Register of Dishonest Tenants, based on their professional experience and an analysis of recent developments on the Polish market of rental property. The new register would be based on the existing Register of Insolvent Debtors which does not effectively protect the interests of landlords against dishonest tenants. The very name of the proposed register could be an effective deterrent in the fight against dishonest tenant practices. The RDT would constitute a database of occupants who evade their responsibilities under tenancy contracts. The RID contains information about insolvent debtors, whereas the proposed instrument would list dishonest tenants. The concept of a dishonest tenant should be defined in legal regulations for the RDT to deliver the expected result. The relevant definition was proposed in the article. The authors also postulated the need for a statutory definition of commercial premises and their functions. The amount of court fees for entering dishonest tenants in the proposed register and deleting register entries remains debatable. A low fee would encourage landlords to register dishonest tenants, and it would provide them with greater access to information about prospective tenants' eligibility to dwell in rented property.

To conclude, Poland's rapidly developing market of residential and commercial rental property is in dire need of a new legal instrument that would effectively protect the interests of landlords against dishonest tenants, and the proposed RDT offers such a tool.

\section{BIBLIOGRAPHY}

Augustyniak H., Łaszek J., Olszewski K., Waszczuk J., Kupić czy wynając? Analiza decyzji podmiotów na rynku mieszkaniowym determinowanych politykq mieszkaniowa. Raport o sytuacji na rynku nieruchomości mieszkaniowych i komercyjnych w Polsce w 2012 r. Warszawa 2013.

Cushman \& Wakefield, Dobre wyniki polskiego rynku nieruchomości komercyjnych, http:// www.cushmanwakefield.pl/pl-pl/news/2015/03/favourable-results-of-the-polish-commercial-property-market (15.08.2015). 
Cushman \& Wakefield, Raport o rynku nieruchomości w Polsce. Jesień 2015, Warszawa 2015.

Eurostat, http://ec.europa.eu/eurostat (15.08.2015).

Foryś I., Rynek nieruchomości komercyjnych, [in:] I. Foryś (ed.), Zarzadzanie nieruchomosciami komercyjnymi, Poltext, Warszawa 2006.

Foryś I., Wstęp, [in:] I. Foryś (ed.), Zarzadzanie nieruchomościami komercyjnymi, Poltext, Warszawa 2006.

Głowny Urząd Statystyczny, Prognoza ludności na lata 2014-2050, Warszawa 2014.

Kucharska-Stasiak E., Nieruchomości w gospodarce rynkowej, PWN, Warszawa 2006.

Nalepka A., Zarządzanie nieruchomościami. Wybrane zagadnienia, Wydawnictwo Akademii Ekonomicznej w Krakowie, Kraków 2006.

Ramian T., Funkcje i klasyfikacja nieruchomości, [in:] H. Henzel, Inwestycje na rynku nieruchomości, Wydawnictwo Akademii Ekonomicznej w Katowicach, Katowice 2004.

Stein J.C., Prices and trading volumes in the housing market: a model with down-payment effects, "Quarterly Journal of Economics", Vol. 110, No. 2/1995, http://dx.doi. org $/ 10.2307 / 2118444$.

Trojanowski D., Nieruchomość komercyjna i jej miejsce, "Nieruchomości C.H. Beck", No. $4 / 2002$.

Ustawa z dnia 15 grudnia 2000 r. o spótdzielniach mieszkaniowych (The Act on housing cooperatives of December 15, 2000), Dz.U. 2001, No. 4, item 27.

Ustawa z dnia 21 czerwca 2001 r. o ochronie praw lokatorów, mieszkaniowym zasobie gminy $i$ o zmianie Kodeksu cywilnego (Act on the protection of tenant rights, municipal housing resources and amendments to the Civil Code of June 21, 2001), Dz.U. 2001, No. 71, item 733.

Ustawa z dnia 23 kwietnia 1964 r. Kodeks cywilny (Civil Code), Dz.U. 1964, No. 16, item 93.

Ustawa z dnia 24 czerwca 1994 r. o wtasności lokali (Act on property ownership of June 24, 1994), Dz.U. 1994, No. 85, item 388.

Ustawa z dnia 26 października 1995 r. o niektórych formach popierania budownictwa mieszkaniowego oraz o zmianie niektórych ustaw (Act on selected incentives promoting housing construction of October 26, 1995), Dz.U. 1995, No. 133, item 654.

Ustawa $z$ dnia 6 lipca 1982 r. o ksieggach wieczystych $i$ hipotece (Act on land and mortgage registers and mortgages of July 6, 1982), Dz.U. 1982, No.19, item147. 